Journal of Epidemiology and Public Health (2016), 1(2): 118-124

https://doi.org/10.26911/jepublichealth.2016.01.02.05

\title{
Analysis of Inputs in the Sexually Transmitted Infection Screening with Voluntary Counselling and Testing Program for Female Prisoners at Class II A Jail, in Malang
}

\author{
Rosyidah Alfitri'), Argyo Demartoto²), Eti Poncorini Pamungkasari3) \\ 1)Diploma III School of Midwifery, Dr. Soepraoen Hospital, Malang \\ 2)Faculty of Social and Political Sciences, Universitas Sebelas Maret \\ 3)Faculty of Medicine, Universitas Sebelas Maret
}

\begin{abstract}
Background: The increasing incidences of Sexually Transmitted Infection (STI) and Human Immonodeficiency Virus (HIV) infection are becoming serious public health concerns in Indonesia and other countries. These issues are of concern that call for close attention not only for general public but also for male and female prisoners. As studies have shown the prevalences of HIV and syphilis were $1.1 \%$ and $5.1 \%$ in male prisoners, respectively, $6 \%$ and $8.5 \%$ in female prisoners. For those reasons, at some jails Voluntary Counseling and Testing (VCT) have been provided for HIV/AIDS control and prevention. The success of the screening program with VCT would depend on the provision of supplies, equipment, infrastructure, health personnel, and fund. This study aimed to analyze the adequacy of various inputs in the STI screening program with VCT for prisoners at the Class II A female jail, in Malang, East Java.

Subjects and Method: This was a qualitative study with evaluation approach. This study was conducted at the Class II A female jail, in Malang, East Java. The study applied CIPP (Context, Input, Process, Product) evaluation model. Key informants for this study included health personnels at the Class II A female jail clinics, in Malang, East Java, the STI mobile health care team from Arjuno Community Health Center Malang, and female prisoners, who were known as Warga Binaan Pemasyarakatan (WBP).

Results: Average monthly visits at the VCT clinic were 21 female prisoners, which amounted to only a few of the total number of female prisoners. The health care team involved in the STI screening with VCT program, included skilled health personnel from the jail and the mobile STI team from Arjuno Community Health Center, Malang. The sources of fund for these programs came from the international as well as domestic funding agencies. The international funding came from the Global Fund. The domestic funding came from the Ministry of Law and Human Civil Rights, and the Municipality Health Office Malang, which provided reagents and medicine. Supplies, equipments, and infrastructure, were provided by Arjuno Community Health Center Malang and the Class II A female jail clinics, in Malang. The laboratory was provided by the health center. The reagents were sufficiently provided by the municipality health office, although there was a supply delay in February 2016.

Conclusion: Inputs of the STI screening with VCT program at the Class II A female jail clinics, in Malang, East Java, which included supplies, equipment, infrastructure, health personnel, and funding, are sufficiently provided.
\end{abstract}

Keywords: analysis, input, screening, STI, VCT

Correspondence:

Rosyidah Alfitri. Diploma III School of Midwifery, Dr. Soepraoen Hospital, Malang. Email: elfitri.mafaza@gmail.com. 


\section{BACKGROUND}

Sexually transmitted infections (STI) and Human Immunodeficiency Virus are significant public health problems and they become the world's concerns, including Indonesia. STI is a series of diseases with diverse infection etiology in which sexual transmission plays key role in its epidemiology, although sometimes it is transmitted through different modes, such as motherto-child transmission, blood and tissue transfer. STI transmission risks are not known by high risk groups, and awareness for uptaking voluntary counselling and testing or VCT is low (Ministry of Health, 2011; Diez et al., 2011).

One of the effective ways to control STI and HIV is regular STI reporting and examination. In the Global Strategy for the Prevention and Control of Sexually transmitted Infections in 2006 - 2015, the World Health Organization has stated that regular STI reporting and examination is a crucial and effective STI monitoring system. Good monitoring system requires the national health authority, policy makers and STI related program managements to monitor and control STI progresses effectively (WHO, 2007).

HIV and cyphillis prevalence among male prisoners are $1.1 \%$ and $5.1 \%$, respectively; the percentage is higher among female prisoners, i.e. $6 \%$ and $8.5 \%$ (Indonesian Ministry of Health and Indonesian Ministry of Law and Human Rights, 2012). The number of people infected by HIV in Malang City has decreased in the last three years, from 466 people in 2014 to 304 people in 2015 .

Provision of accessible and effectively used health facilities is crucial in STI control and eradication measures.

Both in the developed and developing countries, patiens have three options of STI examinations, i.e. treatment at govern- ment-owned clinics (in Indonesia, this service is provided by government-owned hospitals or community health centers/ Puskesmas), private clinics or informal sectors. In order to assure that STI programs are implemented, it is noted that patiens will search for a combination of the three service providers. As part of excellent program planning, competencies of health professionals need to be improved so that they are able to provide quality STI services (Ministry of Health, 2011).

This study applied CIPP evaluation model developed by Stufflebeam (2003) with comprehensive evaluation on the programs, projects, personnels, products, institutions, and system. The study aimed to analyze input on the STI screening program using VCT in Class IIA jail in Malang City, East Java.

\section{SUBJECTS AND METHOD}

This study used qualitative method with evaluation approach. The researcher analyzed inputs for the implementation of STI screening with VCT in Class II A female jail in Malang City. Subjects under the study included health personnels and the prison officials, STI mobile team of Puskesmas Arjuno in Malang City, and the prisonners.

The subjects were selected using purposive sampling technique in conditions that the subjects were the program implementers, both from the prison and puskesmas, and prissonners who have participated in STI screening and VCT. The subjects covered key informants, i.e. the prison's health personnels who led to the key informants and triangulations. The key informants included mobile STI team of Puskesmas Arjuno, Malang City and the prisonners who have participated in the screening.

The triangulation informants under the study were the Head of Disease Pre- 
Journal of Epidemiology and Public Health (2016), 1(2): 118-124

https://doi.org/10.26911/jepublichealth.2016.01.02.05

vention and Control Department (P2PL) of Malang City Health Office and the officials of the female prison in Malang City. The informants were selected using purposive sampling.

Data were collected through indepth interview and observation. The researcher used guided interview as an instrument and other instruments, such as recorder and camera, field notes, and observation results. The data were analyzed, reduced, presented and conculded. Triangulation was conducted to the collected data to confirm the information (Idrus, 2009; Miles dan Huberman, 2014).

\section{RESULTS}

Input analysis in the STI screening with VCT for the prisonners at class II A female jail in Malang City is a program to fight against HIV/ AIDS. This once-in-a-month program has been conducted since 2008 . The screening preparation includes cooperation with Malang City Health Office, facilities and equipment, health professionals.

\section{Requirements}

STI screening with VCT at class II A female jail in Malang City has requirements to make the program implemented and activities conducted. Some informants mentioned the requirements, which included facilities and equipment, health professionals, and medication.

"The requirement of the program implementation includes cooperation with Malang City Health Office because the jail does not have its own laboratory, so at that time (the jail) has worked with Puskesmas Arjuno; reagent, trained staff, counsellors, and other facilities and equipment are provided by the health office. (We) bought a gyn bed. Speculums were from the Directorate General that came from HCI. " (IK1).
"Definitely the trained staff, laboratorium tools (are provided) under cooperation with Malang City Health Office, device availability, counsellor from the jail who is myself" (IK 2)

"The point is that they send a proposal to request assistance for mobile VCT in jail because they are constrained with facilities and equipment and other issues. They send a proposal to the health office, then the office sends puskesmas to provide mobile services there. That's how it begins" (IU 1).

\section{Funding Sources}

The STI screening with VCT in jail has both internal and external funding sources. Internally, the funding comes from the Ministry of Law and Human Rights using the national government budget and expenditure; and the external funding comes from Global Fund and health office which is disbursed in the form of reagents. Using this fund, the screening program is implemented; and the covered expenses include reagents, medicine, transportation fee for the staff who conduct the STI screening with VCT.

The indepth interview finds that, within Global Fund funding scheme, the person in charge who monitors and evaluate the activities is the jail physician. Reagents and medicines are provided by Malang City Health Office.

Below are the information regarding the financing:

"Budget for the STI screening program (assisted by health office) covers STI mobile team (labor), some medicines are from the health office and some others are purchased using the Budget Realization List (DIPA) of clas II A female jail, Malang City. VCT Program: (GF-NFM Program) for VCT mobile acitivities" (IK1).

"There is no budget from the jail/ DIPA. The VCT program implementation is 
assisted by a donor, i.e. GF NFM in which expenses are reimbursed every three months. The budget is used to pay for honorarium of the mobile VCT staff from Puskesmas Arjuno and transportation fee of the logistic staff. STI medicines are provided by Malang City Health Office" (IK 2).

This statement is supported by the Head of $\mathrm{P} 2 \mathrm{Pl}$, Malang City Health Office and the nurse of Puskesmas Arjuno, Malang city as follow:

"...from the local government budget and expenditure and GF. Now, it has changed to be NFM, no longer GF. New funding mechanism..." (IP 1).

"Yes GF. Last year, GF (fund) went to Puskesmas; but this year it goes to the jail. So, I do not know about medicine and other stuff because the jail manage them. The GF is from the jail; it is specifically for our mobilization. In addition, we send monthly patient data to the health office; it relates to the National AIDS Comission (KPA), we also receive a number of patients; but the patients that can be claimed are only those belong to the key population, such as female sexual workers or injecting drug users (IDUs). They can be claimed. Although we have 100 patients, but only five of them belong to the key population, we can only claim for five people. The same thing applies for the jail" (IU 2).

\section{Facilities and Equipment}

Facilities and equipment that support the STI screening and VCT become an important procurement process in the program implementation. The facilities and equipment in the jail are not adequate to conduct the VCT itself; it does not have laboratory and reagents so that these facilities need to be provided by the jail and Puskesmas Arjuno, Malang City. The jail send a proposal to request a gyn bed, speculums, and other supporting devices to the Directorate General of Corrections. Puskesmas Arjuno, Malang City provides laboratory devices such as microscopes, centrifuge, reagents, and other equipment. This is described by the key and primary informants as follow: "For examination, we bring everything from here. It seems there is no equipment because we provide and conduct the tests until we get the results and prescribe therapies. The medicines are provided by the jail" (IU1).

"Available, STI: from the female jail include vaginal speculums, a gyn bed, STI therapeutic medicine. VCT: counsellors are from the jail. Puskesmas Arjuno provides laboratory, reagents, centrifuge, microscopes, laboratory staff, rapid test panel" (IK 1).

\section{Health Professionals}

The screenings both for STI and HIV are conducted by skillful personnels. The personnels are from the STI/ VCT mobile team of Puskesmas Arjuno, Malang City. Through this cooperation, the screening is expected to be carried out once a month.

The researcher observed that the health professionals involved in STI screening with VCT in Class II A female jail, Malang city were Puskesmas Arjuno STI/ VCT mobile team that consisted of one physician, two nurses, 1 laboratory operator, one midwife, and one environmental health staff. They work according to their own capacity.

Below are the description on facilities and equipnment by the informants:

"...the physician is me, but if I am not able to come, another physician replaces me. Nurses are responsible to take secretion; there are one midwife, one nurse, one analyst, one sanitarian, and one driver" (IU1).

"Female jail in Malang: one physician, two nurses, three counsellors. Mobile 
Journal of Epidemiology and Public Health (2016), 1(2): 118-124

https://doi.org/10.26911/jepublichealth.2016.01.02.05

STI/ VCT team of Puskesmas Arjuno: one physician, one monitoring and evaluation officer, two nurses, one analyst/ laboratory" (IK2).

"Physicians at the jail: as the trained physician for STI and CST (care, support, and treatment). Nurses at the jail: HIV counsellors abd STI mobile team from Puskesmas Arjuno" (IK1).

\section{Reagent Availability}

Reagent is a substance needed for chemical reactions in a specific testing. The reagents used in HIV and STI testing in Class II A female jail in Malang City is provided by the city health office and distributed to all puskesmas in the area. The researcher conducted document analysis to the VCT and STI testing books. In February, the screening was not conducted because the reagent was not available due to failed auction.

Followings are the statements of the IK2 as the nurses of Class II A, female jail, Malang City and IU1 as the physician of Puskesmas Arjunoa, Malang City:

"STI medicines are provided by Malang City Health Office; and the medicine availability relies on the supplies in the health office's pharmaceutical storage" (IK2).

"We bring the reagents, but the medicines are from there. So, we are until diagnosis, the therapy is provided by there, the medicines are also from the jail...once it was late. Usually we postpone, then we collect until next month, until the reagents arrive. Yes, the delay is from the health office, usually it is short, not long" (IU1).

Statements on the reagents availability were also made by the Head of Diseases Control of Malang City Health Office as the supporting informant 1; information on the delayed reagents was also provided by the nurses as the primary informant 2 . Following are the statements:

"Alhamdulillah (Praise be to God), it is not late. It was late once due to failed auction..it was still manageable, still available because (the stock) is not empty. Alhamdulillah, we are still allowed. But the reagent is procured jointly by the national government and the local government budget and expenditure 2 (APBD2). The reagents procured using $A P B D 2$ is only for Malang City, particularly the puskesmas. The jail comes from both outside and within the area, we use the provincial budget, so we are sharing to avoid those coming from Malang City, coming from outside the city are not served." (IP1).

"As for the reagents, we certainly take them from the health office; how the office gets them, I do not know. The point is that when the reagents ran out, we ask for them. So far, it is not late. It happened once. But it was not long. The reagents were immediately available." (IU 2).

\section{Implementation Schedule}

The STI screening with VCT at Class II A female jail, Malang City based on the plan and agreement of the two parties is scheduled on the third Friday of the month. So, the program is conducted once a month.

The indepth interview with the informants on the screening schedule found that the schedule was tentative depending on the community health center's activities. The program is likely to be postponed, moved forward or not being conducted in the particular month due to personnels shortage or the puskesmas's priomary activities. This finding is supported by the statement of IK2 as a nurse and consellor at the jail:

"Yes, on the third Friday of the month. But, if the schedule changes due to some reasons, it is informed or confirmed in advanced" (IK 2). 
Similarly, IK1 as the physician at the jail and IU1 as the physician of Puskesmas Arjuno, Malang City described below:

"Scheduled. The counselling is on Thursdays, and the test is on the third Friday" (IK 1).

"It was delayed, it moved forward, and we didn't go to the jail in that month due to the personnel shortage because my team had to be full, whereas the puskesmas also had a lot of programs. All of us are multi-tasked, some go to trainings, some others are on maternal leave, like me" (IU 1)

\section{DISCUSSION}

The input analysis on this program evaluation include health professionals, implementation schedule, funding sources, facilities and equipment, and reagent availability. The involved health professionals are human resources who play significant roles in the STI screening with VCT at Class II A female jail in Malang City.

The health professionals involved in the STI screening with VCT are the trained health workers, and the VCT is conducted at puskesmas, hospitals and mobile services provided by the trained personnels (Cheng et al., 2016). The trained health professionals have become a requirement in the service provision or treatmeant provision based on SOP.

The trained health professionals who work in the jail give informed consent to every prisoner or new prisoners to agree on Tubercolusis and Syphillis testing, but the HIV testing is voluntary (Rosena et al, 2015). At Class II A female jail, Malang City, general examination is conducted but it is constrained with facilities and equipment; the examination is scheduled once a month.

Funding for the STI screening with VCT comes from external institutions, i.e
Global Fund and Malang City Health Office. This activity covers VCT and STI tests. Each activity receives support from outside the Directorate General of Corrections of the Ministry of Law and Human Rights. The VCT is financed by GF and some of the ragents are from Malang City Health Office. STI testing is supported by Malang City Health Office. Funding is not only provided to Indonesia. In China, free HIV services are assisted by international donors so that the number of people who are examined increases in the last decade (Cheng et al., 2016). International financing is truly helpful to improve services for high risk groups and people in general.

Facilities and equipment in the STI screening with VCT program provided by the mobile STI team of Puskesmas Arjuno, Malang City include microscopes, centrifuge, and others. The jail provides other supporting equipment such as gyn bed, spotlight, waiting room, tables and chairs for the mobile STI team members and the prisoners.

The reagent availability in the screening program at Class II A female jail, Malang City depends on the supplies of the city health office that is distributed by Puskesmas Arjuno, Malang City. The reagent supplies were adequate until December 2016. The reagent was late in February 2016 because of failed auction. The delayed was not long, and the need was fulfilled immediately.

\section{REFERENCE}

$\overline{\text { Cheng (2016). Late presentation of HIV }}$ infection: Prevalence, trends, and the role of HIV testing strategies in Guangzhou, China, 2008-2013. BioMed Research International, 7: 1631878.

Díez, Díaz (2011). Sexually transmitted infections: Epidemiology and control. 
Journal of Epidemiology and Public Health (2016), 1(2): 118-124

https://doi.org/10.26911/jepublichealth.2016.01.02.05

Epidemiology Department on HIV and Risk Behaviors. National Centre for Epidemiology. Health Institute Carlos III Rev Esp Sanid Penit; 13: 58-66.

Farsi M, Sharif M (2014). Stufflebeam's Cipp \& Program Theory: A Review. International Journal of Language Learning and Applied Linguistics World (IJLLALW) 6(3) : 400-406.

Idrus M (2008). Metode penelitian ilmu sosial; Pendekatan kualitatif dan kuantitatif edisi kedua. Jakarta: Erlangga

Miles M, Huberman A (2014). Analisis data kualitatif; Buku sumber tentang metode-metode baru. Jakarta: UIPress.

Kebijakan Kesehatan Indonesia (2013). Konteks Kebijakan AIDS: Epidemiologi dan Perilaku Beresiko. [online]

Kementerian Kesehatan RI (2011). Pedoman Nasional Penanganan Infeksi
Menular Seksual. Jakarta: Dirjen Pengendalian Penyakit dan Penyehatan Lingkungan.

Kementerian Kesehatan RI, Kementerian Hukum dan HAM RI (2012). Pedoman Pelayanan Komprehensif HIV AIDS \& IMS di Lapas, Rutan dan Bapas. Direktorat Pengendalian Penyakit \& Penyehatan Lingkungan Kemenkes RI dan Direktorat Pemasyarakatan Kemenkumham RI.

Rosena DL (2015). Opt-out HIV testing in prison: Informed and voluntary? AIDS Care; 27(5): 545-554.

WHO, UNODC, UNAIDS (2007). Evidence for action technical papers interventions to address HIV in prisons prevention of sexual transmission. Geneva. 